Article

\title{
Red Light Activation of Ru(II) Polypyridyl Prodrugs via Triplet-Triplet Annihilation Upconversion: Feasibility in Air and through Meat
}

\author{
Sven H. C. Askes, Michael S. Meijer, Tessel Bouwens, Iris Landman and Sylvestre Bonnet * \\ Leiden Institute of Chemistry, Leiden University, Einsteinweg 55, Leiden 2333 CC, The Netherlands; \\ s.h.c.askes@chem.leidenuniv.nl (S.H.C.A.); m.s.meijer@chem.leidenuniv.nl (M.S.M.); \\ tessel.bouwens@student.uva.nl (T.B.); iris.landman@student.uva.nl (I.L.) \\ * Correspondence: bonnet@chem.leidenuniv.nl; Tel.: +31-71-527-4260 \\ Academic Editor: Derek J. McPhee
}

Received: 5 October 2016; Accepted: 26 October 2016; Published: 1 November 2016

\begin{abstract}
Triplet-triplet annihilation upconversion (TTA-UC) is a promising photophysical tool to shift the activation wavelength of photopharmacological compounds to the red or near-infrared wavelength domain, in which light penetrates human tissue optimally. However, TTA-UC is sensitive to dioxygen, which quenches the triplet states needed for upconversion. Here, we demonstrate not only that the sensitivity of TTA-UC liposomes to dioxygen can be circumvented by adding antioxidants, but also that this strategy is compatible with the activation of ruthenium-based chemotherapeutic compounds. First, red-to-blue upconverting liposomes were functionalized with a blue-light sensitive, membrane-anchored ruthenium polypyridyl complex, and put in solution in presence of a cocktail of antioxidants composed of ascorbic acid and glutathione. Upon red light irradiation with a medical grade $630 \mathrm{~nm}$ PDT laser, enough blue light was produced by TTA-UC liposomes under air to efficiently trigger full activation of the Ru-based prodrug. Then, the blue light generated by TTA-UC liposomes under red light irradiation $\left(630 \mathrm{~nm}, 0.57 \mathrm{~W} / \mathrm{cm}^{2}\right)$ through different thicknesses of pork or chicken meat was measured, showing that TTA-UC still occurred even beyond $10 \mathrm{~mm}$ of biological tissue. Overall, the rate of activation of the ruthenium compound in TTA-UC liposomes using either blue or red light $\left(1.6 \mathrm{~W} / \mathrm{cm}^{2}\right)$ through $7 \mathrm{~mm}$ of pork fillet were found comparable, but the blue light caused significant tissue damage, whereas red light did not. Finally, full activation of the ruthenium prodrug in TTA-UC liposomes was obtained under red light irradiation through $7 \mathrm{~mm}$ of pork fillet, thereby underlining the in vivo applicability of the activation-by-upconversion strategy.
\end{abstract}

Keywords: photochemical upconversion; ruthenium prodrugs; phototherapy; liposomes; meat spectroscopy

\section{Introduction}

Among the wide variety of photopharmacological compounds known to date, light-activatable ruthenium polypyridyl complexes have received considerable attention as they represent a promising family of anticancer prodrugs. In a process called "photoactivated chemotherapy" (PACT) [1-5], excitation with visible light transforms these non-toxic compounds into cytotoxic species via photosubstitution reactions. Like in photodynamic therapy (PDT), ruthenium-based PACT agents may greatly reduce undesired side effects for cancer patients by the excellent spatio-temporal control over activation. In addition, it is possible to anchor ruthenium complex to nanoparticles or liposomes, which allows for targeting the compound to tumors by making use of their leaky vasculature via the enhanced permeability and retention (EPR) effect [6,7]. For this class of photopharmacological 
compounds, the light-induced toxicity does not depend on the presence of oxygen, as opposed to photodynamic therapy (PDT) type 2, which functions by generating highly reactive oxygen species (ROS) [8,9]. Thus, using light-activatable Ru-complexes may be suitable for hypoxic tumor tissues for which PDT is not effective. One of the major challenges with ruthenium-based PACT agents is that they are mostly activated with blue or green light, which does not penetrate human tissues very well. Shifting the excitation wavelength of ruthenium complexes to the phototherapeutic window $(600-950 \mathrm{~nm})$ is necessary, but achieving such a shift by molecular design remains very difficult [10-12]. To circumvent this problem, upconverting drug delivery systems have been proposed that can not only transport the prodrug to the tumor, but also locally "upgrade" red or near-infrared photons into blue or green photons with which the prodrug is activated.

a

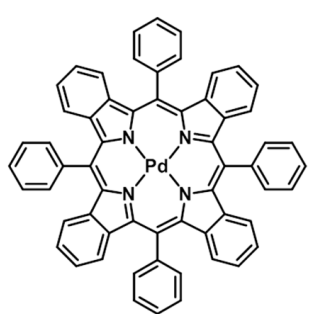

1

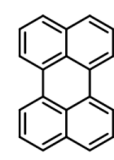<smiles>CC(C)(C)c1ccc2c(c1)cc(C(C)(C)C)c1cc(C(C)(C)C)ccc12</smiles>

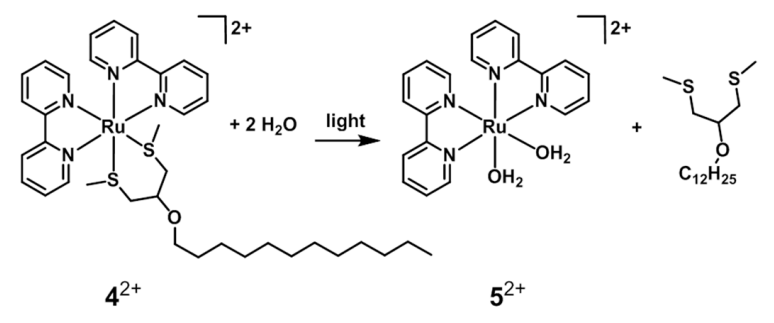

b

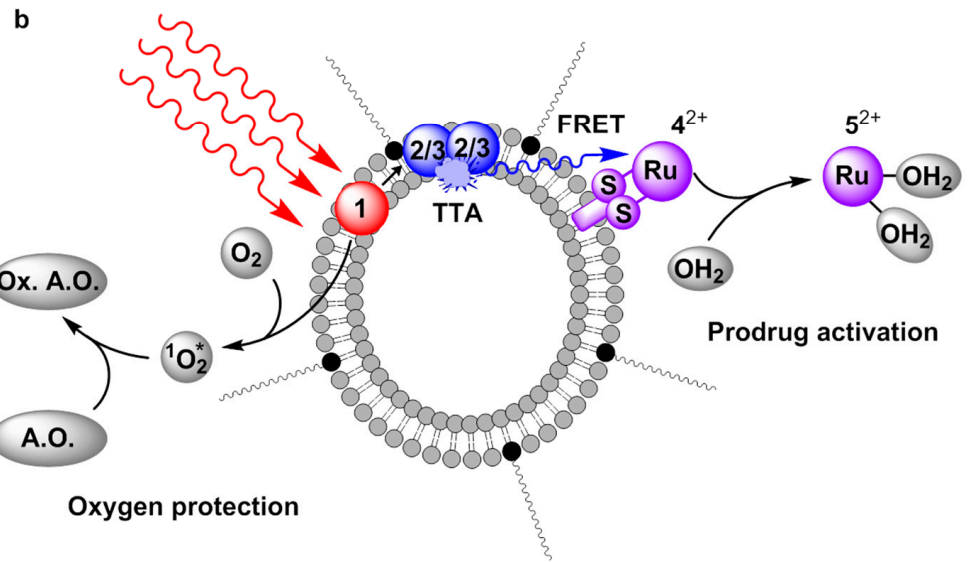

Figure 1. (a) Chemical structures of palladium(II) tetraphenyltetrabenzoporphyrin (1), perylene (2), 2,5,8,11-tetra(tert-butyl)perylene (3), $\mathrm{Ru}(\mathrm{II})$ compound $4^{2+}$ and its photochemical conversion to $5^{2+}$ upon visible light irradiation in presence of water; (b) Cartoon illustrating upconversion mediated Ru-prodrug activation in PEGylated liposomes in presence of antioxidants. Red-to-blue triplet-triplet annihilation (TTA) upconversion in the lipid bilayer is followed by non-radiative energy transfer (FRET) of the upconverted light to $4^{2+}$, and subsequent photochemical reaction of $4^{2+}$ to $5^{2+}$. Meanwhile, an antioxidant (A.O.) protects the photochemical cascade from quenching by dioxygen by consuming the singlet-state oxygen $\left({ }^{1} \mathrm{O}_{2}{ }^{*}\right)$ that is initially generated upon irradiation of $\mathbf{1}$ until all oxygen is consumed. Hereby, the antioxidant becomes oxidized (Ox. A.O.). 
Among the various methods available for performing light upconversion, triplet-triplet annihilation upconversion (TTA-UC) is one of the most advantageous for clinical application, because it requires low excitation intensity (down to $1 \mathrm{~mW} / \mathrm{cm}^{2}$ ), employs sensitizers that have high molar absorptivity in the phototherapeutic window, and typically achieves upconversion quantum yields of $1 \%-5 \%$ also in aqueous solution [13-15]. TTA-UC is based on the photophysical interplay of photosensitizer and annihilator chromophores (see Figure S1) [16,17]. The photosensitizer absorbs low-energy light, after which intersystem crossing leads to a long-lived triplet state. This triplet state is transferred to the annihilator upon diffusional collision by means of triplet-triplet energy transfer (TTET); succession TTET events lead to a concentration buildup of long-lived triplet state annihilators molecules. Two triplet state annihilator molecules interact, resulting in triplet-triplet annihilation, in which one of them departs with all the energy of the pair and reaches a high-energy singlet excited state. Finally, this singlet excited state returns to the ground state by fluorescent emission of a high-energy photon, thereby realizing upconversion. TTA-UC has been demonstrated in various organic, inorganic, and/or supramolecular materials [15,18-22], as well as in nano- or micro-sized particles [23-25]. For biological applications, i.e., for drug delivery and activation [26,27] or bio-imaging $[13,28-33]$, one of the main problems of TTA-UC is its sensitivity to molecular oxygen, which readily quenches the triplet state chromophores involved in the TTA-UC mechanism. To solve this issue, we and others recently showed that antioxidants such as L-histidine, ascorbic acid, or glutathione, can protect TTA-UC against oxygen: upon irradiation of TTA-UC vesicles in air, the photosensitizer initially generates singlet oxygen, which is scavenged by the antioxidant until all oxygen in the irradiated volume has been consumed (Figure 1b) [25,34-37]. Once the $\mathrm{O}_{2}$ concentration reaches a certain threshold, TTA-UC switches on and remains stable for minutes to even hours in spite of the air atmosphere.

Although our group previously demonstrated that blue-light sensitive Ru polypyridyl complex could be effectively activated by a red-to-blue TTA-UC in liposomes (Figure 1b), this demonstration was performed under argon, which is not relevant for clinical applications [26,27]. In the first part of this article, we report that it is possible to solve this issue by using the antioxidant strategy mentioned above. Ruthenium polypyridyl compounds such as $4^{2+}$ (Figure 1a) are known [38,39] to photosubstitute their chelating bis-thioether ligand upon blue light irradiation to produce the cytotoxic species $\left(\mathrm{Ru}(\mathrm{bpy})_{2}\left(\mathrm{OH}_{2}\right)_{2}\right)^{2+}\left(5^{2+}\right.$, Figure 1a) [2]. Usually, antioxidants have also good coordinating properties (e.g., histidine, glutathione, etc.), but our data demonstrate that these coordinating properties do not prevent the triggering of photosubstitution reactions in air for the liposome-bound ruthenium complex $4^{2+}$ using red light and TTA-UC. In the second part of this article, the tissue depth at which TTA-UC is still able to generate blue light is evaluated by shining red light through increasing layers of pork and chicken meat. In the third and final part, we demonstrate not only that it is possible to fully activate the ruthenium prodrug through pork meat and using red light, but that it is also actually more advantageous to use red light instead of blue light, because there is less tissue damage.

\section{Results and Discussion}

\subsection{Liposome Preparation}

PEGylated upconverting liposomes containing or not the ruthenium compound $4^{2+}$ (Scheme 1 ) were prepared by a standard hydration-extrusion protocol [26] in phosphate buffered saline (PBS). Where applicable (see below), before addition of PBS to the lipid film, the buffer was supplemented with a known concentration of L-ascorbic acid (L-Asc) and/or glutathione (GSH) as antioxidants, and neutralized to $\mathrm{pH}$ 7.0-7.6 with $\mathrm{NaOH}$. For all samples the major component of the liposome membrane was a neutral phosphatidylcholine lipid, i.e., either 1,2-dilauroyl-sn-glycero-3-phosphocholine (DLPC, liposome samples are denoted "L" in Table 1) or 1,2-dimyristoyl-sn-glycero-3-phosphocholine (DMPC, liposomes are denoted " $\mathrm{M}$ " in Table 1). The liposomes were PEGylated with $4 \mathrm{~mol} \%$ sodium $N$-(carbonyl-methoxy polyethyleneglycol-2000)-1,2-distearoyl-sn-glycero-3-phosphoethanolamine 
(DSPE-mPEG-2000), which is known to prevent aggregation and to prolong the lifetime of liposomes in the blood circulation [6,7]. Finally, the liposomes were doped with either the TTA-UC dye couple ( $0.05 \mathrm{~mol} \% \mathbf{1}, 0.5 \mathrm{~mol} \% 2)$, or all three components ( $0.05 \mathrm{~mol} \% \mathbf{1}, 1 \mathrm{~mol} \% 3$, and $\left.4 \mathrm{~mol} \% 4^{2+}\right)$; Table 1 summarizes the exact formulation of all liposome samples prepared. All samples were characterized by dynamic light scattering (DLS), which showed that the hydrodynamic size (z-ave) of all liposomes varied from 130-170 $\mathrm{nm}$ with an average polydispersity index (PDI) of 0.1.

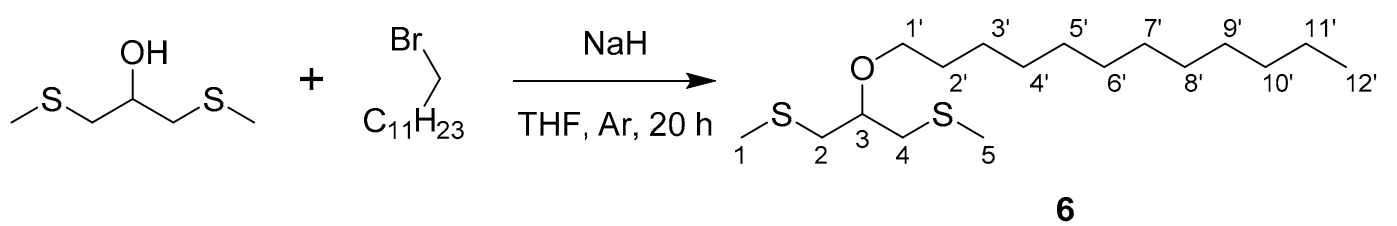

Scheme 1. Synthesis of compound 6 from 1,3-bis(methylthio)-2-propanol and 1-bromododecane.

Table 1. Summary of liposome formulations used in this chapter. Liposomes with designation L or M are made with DLPC or DMPC as main lipid, respectively. Final concentrations are given as bulk concentrations (in $\mathrm{mM}$ or $\mu \mathrm{M}$ ).

\begin{tabular}{cccccccc}
\hline \multirow{2}{*}{ Code } & {$[$ DMPC] } & [DLPC] & [DSPE-mPEG-2000] & [1] & [2] & {$[3]$} & {$\left[4^{2+}\right]$} \\
\cline { 2 - 8 } & $\mathbf{m M}$ & $\mathbf{m M}$ & $\mathbf{m M}$ & $\mu \mathbf{M}$ & $\mu \mathbf{M}$ & $\mu \mathbf{M}$ & $\mu \mathbf{M}$ \\
\hline L12 & & 5.0 & 0.20 & 2.5 & 25 & & \\
L134 & & 5.0 & 0.20 & 2.5 & & 50 & 200 \\
M134 & 5.0 & & 0.20 & 2.5 & & 50 & 200 \\
M34 & 5.0 & & 0.20 & & & 50 & 200 \\
\hline
\end{tabular}

\subsection{Anti-Oxidants Allow Efficient and Stable TTA-UC in Air with L12 Liposomes}

Following our recently published strategy [25], the red-to-blue upconversion of DLPC liposomes L12 was studied in presence of ascorbic acid or glutathione to investigate to which extent upconversion could occur in air. In this study, DLPC was used as main lipid because upconversion was found more efficient at room temperature in DLPC than in DMPC liposomes [40]. Thus, when L12 was irradiated with red light $(630 \mathrm{~nm})$ at a power density of $80 \mathrm{~mW} / \mathrm{cm}^{2}$ in air in presence of $5 \mathrm{mM} \mathrm{L}$-Asc, emission spectra initially showed only weak phosphorescence of $\mathbf{1}$ at $800 \mathrm{~nm}$ and no upconversion emission (Figure 2a, inset). After a "lag time" of $~ 1$ min irradiation, however, the phosphorescence at $800 \mathrm{~nm}$ suddenly intensified and intense upconversion emission at $474 \mathrm{~nm}$ was observed; both emission bands stabilized after 2 min (Figure 2a, inset). The experiment was repeated while probing the dissolved oxygen concentration (Figure $2 b$ ). Oxygen was consumed only very slowly in the dark, but was fully depleted after $5 \mathrm{~min}$ of red light irradiation. These results confirm that the antioxidant scavenges the singlet-oxygen that is generated by the photosensitizer upon irradiation [25,34]. When the experiment was repeated in presence of $0.25-50 \mathrm{mM} \mathrm{L-Asc}$ or 1-20 mM GSH, i.e., close to the biological concentrations of these two species [41], the "lag time" before upconversion progressively decreased with increasing antioxidant concentration to as low as $0.5 \mathrm{~min}$ lag time at $50 \mathrm{mM}$ of L-Asc (Figure S2). It was also found that a "cocktail" containing both L-Asc and GSH synergistically minimized the lag-time: for a mixture of $1 \mathrm{mM} \mathrm{L}$-Asc and $5 \mathrm{mM} \mathrm{GSH}$ the lag-time was $1.1 \mathrm{~min}$, which was significantly shorter than that found with either of the antioxidants alone ( $3.2 \mathrm{~min}$ for $1 \mathrm{mM} \mathrm{L}-$ Asc and $13 \mathrm{~min}$ for $5 \mathrm{mM}$ GSH). Therefore, a combination of these two antioxidants was used in all further experiments. From this first set of data, it appeared clearly that the addition of biologically relevant concentrations of antioxidants to upconverting liposomes results in stable red-to-blue TTA-UC in air. 

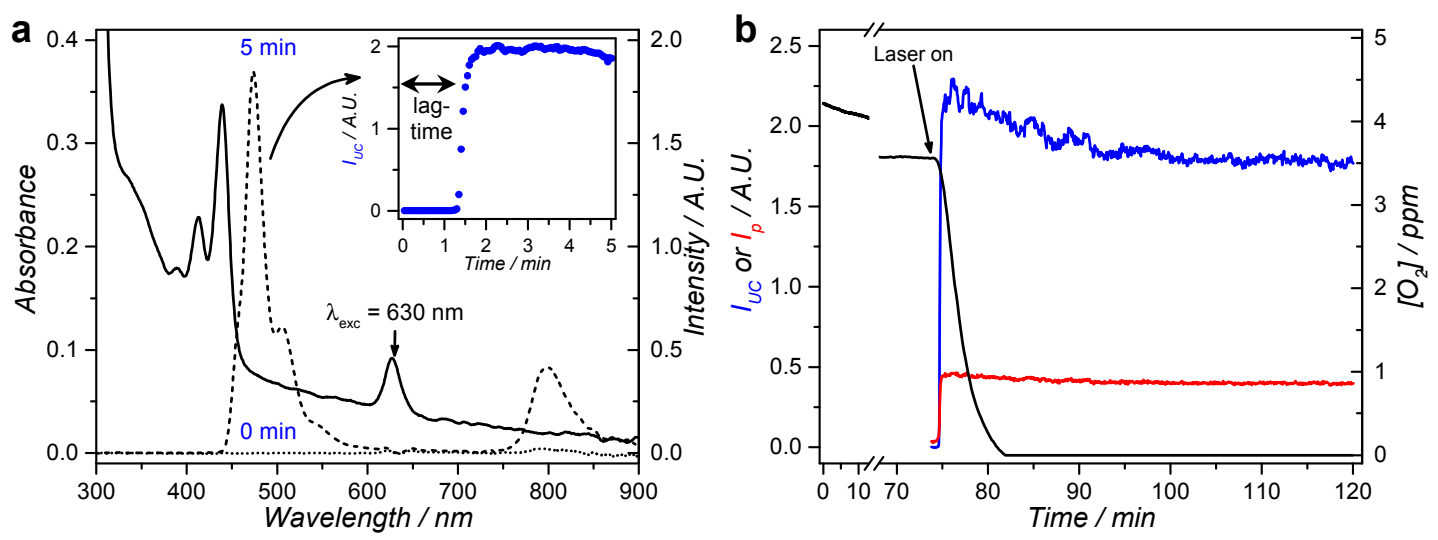

Figure 2. Emission spectroscopy in air of L12 liposomes in PBS supplemented with L-Asc or GSH. (a) Absorption (solid) and emission spectra (dotted: $t=0$; dashed: $t=5 \mathrm{~min}$ ) of L12 liposomes in PBS supplemented with $5 \mathrm{mM}$ L-Asc. Inset shows the upconversion intensity ( $I_{U C}$ at $474 \mathrm{~nm}$ ) for the first 5 min of irradiation with 3 s intervals; (b) Time trace of the upconversion intensity ( $I_{U C}$ at $474 \mathrm{~nm}$, blue), phosphorescence intensity $\left(I_{p}\right.$ at $800 \mathrm{~nm}$, red), and dissolved oxygen concentration (black) during red light irradiation of $\mathbf{L 1 2}$ liposomes in PBS supplemented with $5 \mathrm{mM} \mathrm{L-Asc}$. The laser was turned on after $74 \mathrm{~min}$ in the dark, as indicated by the arrow. Exp. conditions: [DLPC] $=1 \mathrm{mM},[1]=0.5 \mu \mathrm{M},[2]=5 \mu \mathrm{M}$, $2.25 \mathrm{~mL}$ sample, $\mathrm{T}=20^{\circ} \mathrm{C}, 10 \mathrm{~mW} 630 \mathrm{~nm}$ laser excitation $\left(80 \mathrm{~mW} / \mathrm{cm}^{2}\right)$ with approximately $8 \%$ of the volume simultaneously irradiated, $\mathrm{pH}$ 7.0-7.6.

\subsection{Activation of a Photodissociative Ruthenium Complex Using Upconverting DMPC Liposomes in Air}

To investigate whether antioxidants could also protect the upconversion-mediated photoactivation of $4^{2+}$ in air, M134 liposomes were prepared at $1 \mathrm{mM}$ bulk DMPC concentration that contained red-to-blue TTA-UC dye couple 1 and 3 , and the photodissociative ruthenium compound $4^{2+}$. The photodissociation reaction with red light irradiation was performed in either deoxygenated conditions using argon bubbling for $30 \mathrm{~min}$, or in air-equilibrated solution containing $10 \mathrm{mM}$ L-Asc and $10 \mathrm{mM} \mathrm{GSH}$. Both samples were irradiated at human body temperature $\left(37^{\circ} \mathrm{C}\right)$ with $630 \mathrm{~nm}$ light $\left(150 \mathrm{~mW}, 1.2 \mathrm{~W} / \mathrm{cm}^{2}\right)$ for $2.5 \mathrm{~h}$ while recording the $\mathrm{UV}$-vis absorbance (Figure $3 \mathrm{a}, \mathrm{b}$ ) and emission spectra every $15 \mathrm{~min}$. The UV-vis spectrum at $t=0$ shows the characteristic absorption bands of 1 at 440 and $630 \mathrm{~nm}$, of 3 between 375 and $450 \mathrm{~nm}$, while the absorbance of $4^{2+}$ (Figure S3) is hidden under the bands of $\mathbf{1}$ and $\mathbf{3}$. Under argon and in absence of antioxidants, the absorption band of the photoproduct $5^{2+}$ evolves to completion within the first hour of irradiation, just as observed for complex $4^{2+}$ in water upon blue light irradiation (Figure S4). By plotting the absorbance at $490 \mathrm{~nm}$ versus time (Figure 3c), it is clear that the photoreaction was completed after about $45 \mathrm{~min}$ of irradiation $\left(40 \mu \mathrm{mol} 4^{2+}\right.$ converted to $\left.5^{2+}\right)$. While the photoreaction was progressing, the upconversion emission at $486 \mathrm{~nm}$ increased (Figure $3 \mathrm{~d}$ ) because complex $5^{2+}$ dissociates from the membrane into the solution, thereby no longer quenching the emission of 3 via FRET (see Figure S3 for overlap between 3 and $4^{2+}$ ) [26]. After 60-90 min of irradiation, both the absorption and emission spectra completely stabilized, showing that photosubstitution reaction was completed.

When red light irradiation was conducted in air and in presence of antioxidants, the same absorption band between 460 and $600 \mathrm{~nm}$ appeared in the first $30 \mathrm{~min}$ of irradiation (Figure 3b), which strongly resembled the absorption band of $5^{2+}$. After that time-point however, this absorption band slowly disappeared, indicating that the photoproduct $5^{2+}$ was not stable upon prolonged irradiation, and/or that it further reacted with L-Asc or GSH, for example by coordination. Like in the previous experiment, the upconversion emission intensity increased in the first two hours of irradiation, revealing that the photoproduct was leaving the membrane of the liposome. As a control, the irradiation experiment under argon was repeated with M34 liposomes, which did not contain photosensitizer $\mathbf{1}$ and hence could not produce TTA-UC. A slow evolution of the absorbance at 490 was 
observed, which is attributed to direct absorption of the red light by $4^{2+}$ due to the low but non-zero absorption of the complex at $630 \mathrm{~nm}$. Overall, these results demonstrate that light upconversion in air was efficient enough to greatly amplify the rate of photodissociation upon red light irradiation.
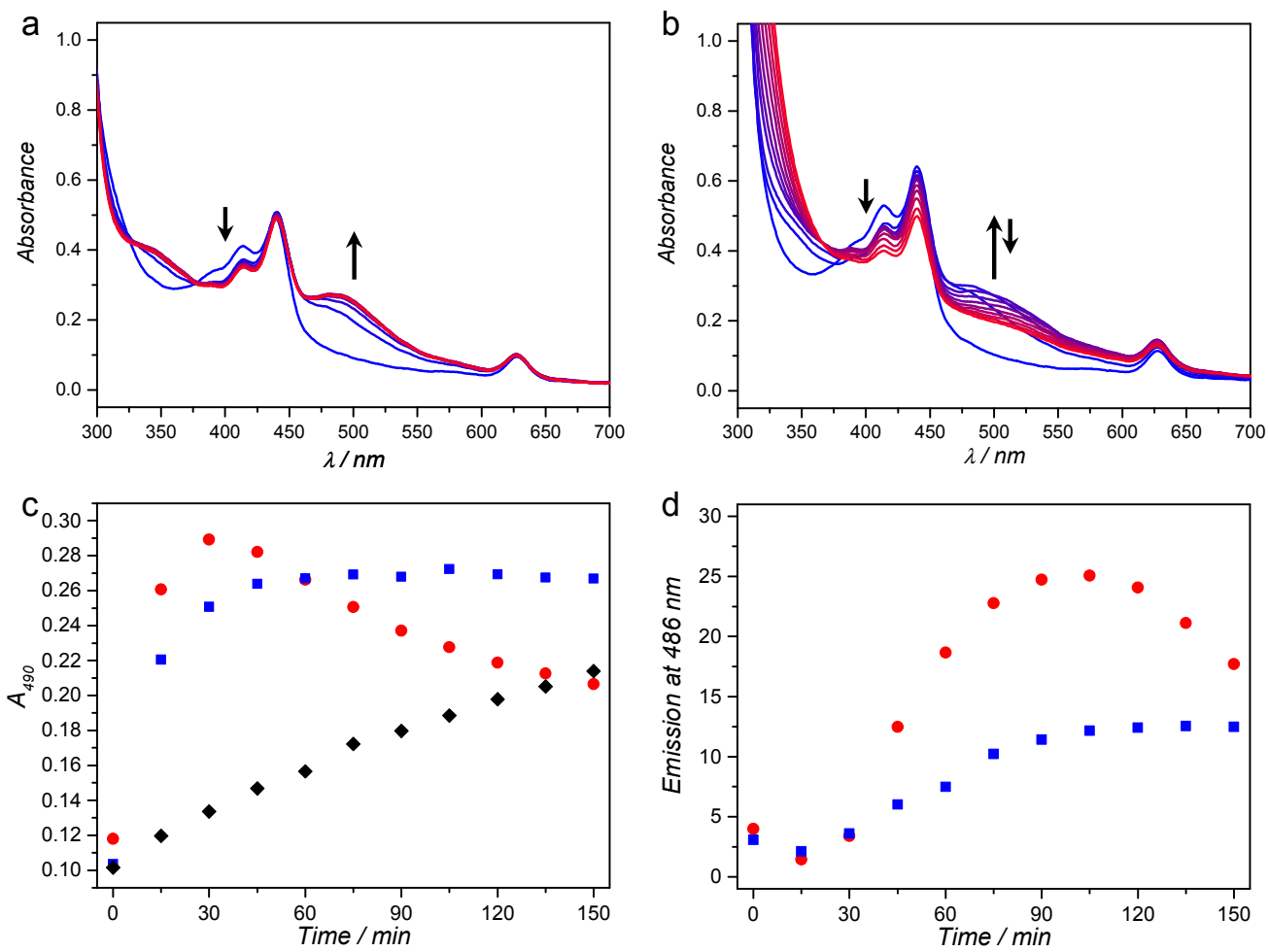

Figure 3. UV-vis absorption spectroscopy in $15 \mathrm{~min}$ intervals (gradient) during red-light irradiation of M134 liposomes under: argon (a); and in air in presence of $10 \mathrm{mM} \mathrm{L-Asc}$ and GSH (b). Absorbance at $490 \mathrm{~nm}$ (c); and upconversion emission at $486 \mathrm{~nm}$ (d) as a function of time for the experiment under argon (blue squares) and in air in presence of antioxidants (red circles). As control, M34 liposomes were irradiated under the same conditions under argon (c) (black diamonds). Conditions: $2 \mathrm{~mL}$ sample with $1 \mathrm{mM}$ DMPC, irradiated at $37{ }^{\circ} \mathrm{C}$ with $150 \mathrm{~mW} 630 \mathrm{~nm}$ light $\left(1.2 \mathrm{~W} / \mathrm{cm}^{2}\right)$. Arrows indicate the evolution of the spectrum in time at the indicated wavelengths (400 and $500 \mathrm{~nm}$ ).

One of the remaining questions was whether the photoproduct obtained in air with antioxidants was identical to that obtained under argon. To answer this question, the irradiation experiments were repeated, but stopped after $60 \mathrm{~min}$; the liposomes were removed from the solution using a centrifugal filtration, and a UV-vis absorption spectrum of the filtrate was recorded. When irradiation was performed under argon, the UV-vis absorption spectrum of the filtrate was identical to the absorption spectrum of $5^{2+}$ (Figures S4 and S5), thereby confirming the photodissociation reaction of $4^{2+}$ to $5^{2+}$. When irradiation was performed in air and in presence of antioxidants, the absorption spectrum of the filtrate was very similar to that of $5^{2+}$, suggesting that the same (or a similar) Ru-complex had been formed. As control, no absorption was detected for filtered solutions of M134 liposomes kept in the dark under argon or with antioxidants. Finally, red light irradiation of M134 was repeated at higher liposome concentration (20 mM DMPC), and mass spectra were recorded after centrifugal filtration, lyophilisation of the filtrate, and redissolving the residue in acetone (Figure S6). In case of irradiation under argon, the main peaks at $m / z=490.1$ and 507.1 belonging to $\left[\mathrm{Ru}(\mathrm{bpy})_{2}\left(\mathrm{OH}_{2}\right)(\mathrm{OH})\right]^{+}$ $(\mathrm{MeCN})$ and $\left[\mathrm{Ru}(\mathrm{bpy})_{2}\left(\mathrm{OH}_{2}\right)(\mathrm{OH})\right]^{+}$(acetone), respectively, confirmed that $5^{2+}$ had indeed formed. In the case of irradiation in air in presence of antioxidants, the sample only dissolved in methanol, which suggests that another Ru-complex had been formed. The mass spectrum showed peaks at $m / z=481.1$ and $490.0 \mathrm{~m} / z$, belonging to $\left[\mathrm{Ru}(\mathrm{bpy})_{2}\left(\mathrm{OH}_{2}\right)(\mathrm{OH})\right]^{+}(\mathrm{MeOH})$ and $\left[\mathrm{Ru}(\mathrm{bpy})_{2}\left(\mathrm{OH}_{2}\right)(\mathrm{OH})\right]^{+}$ 
(MeCN) (Figure S7). Although no signals were detected from a GSH complex, for example at $m / z=738.1$ for $\left[\mathrm{Ru}(\mathrm{bpy})_{2}(\mathrm{GS})\left(\mathrm{H}_{2} \mathrm{O}\right)\right]^{+}$, it is still plausible that compound $5^{2+}$ and products such as GSH adducts co-exist in the reaction mixture. Overall, these results show that the addition of GSH and L-Asc allowed the red light induced photoactivation cascade of TTA-UC, non-radiative energy transfer, and photosubstitution on ruthenium, to function in air.

\subsection{At Which Tissue Depth Can Red-to-Blue TTA-UC Be Generated?}

A priori, the reason to use red-to-blue light upconversion for photoactivation chemotherapy is the increased excitation penetration depth of red light in tissues. However, up to now it remained unknown at which tissue depth red-to-blue TTA-UC can occur with liposomes. To answer this question in a model of healthy human tissue, an upconverting gel was first prepared by mixing L12 liposomes $([D L P C]=10 \mathrm{mM}$ ) with $0.5 \mathrm{wt} \%$ agarose and $5 \mathrm{mM} \mathrm{L}$-Asc and GSH in PBS (see Figure 4a for a photograph of the gel in bulk). This gel was then deposited as a thin disk between two microscopy slides, and further covered with a variable stack of thin slices (1-2 mm thick) of raw chicken breast or pork fillet to mimic human tissue of different color and structure. Finally, a $630 \mathrm{~nm}$ laser beam $\left(0.57 \mathrm{~W} / \mathrm{cm}^{2}\right)$ was directed perpendicularly to the meat, thus exciting the upconverting liposome gel at a power density that depended on the thickness of the meat layer above it. The emission spectrum of the upconverting gel was measured on the other side of the sample, thus in transmission mode, using a custom-made cage spectroscopy setup (Figure 4).
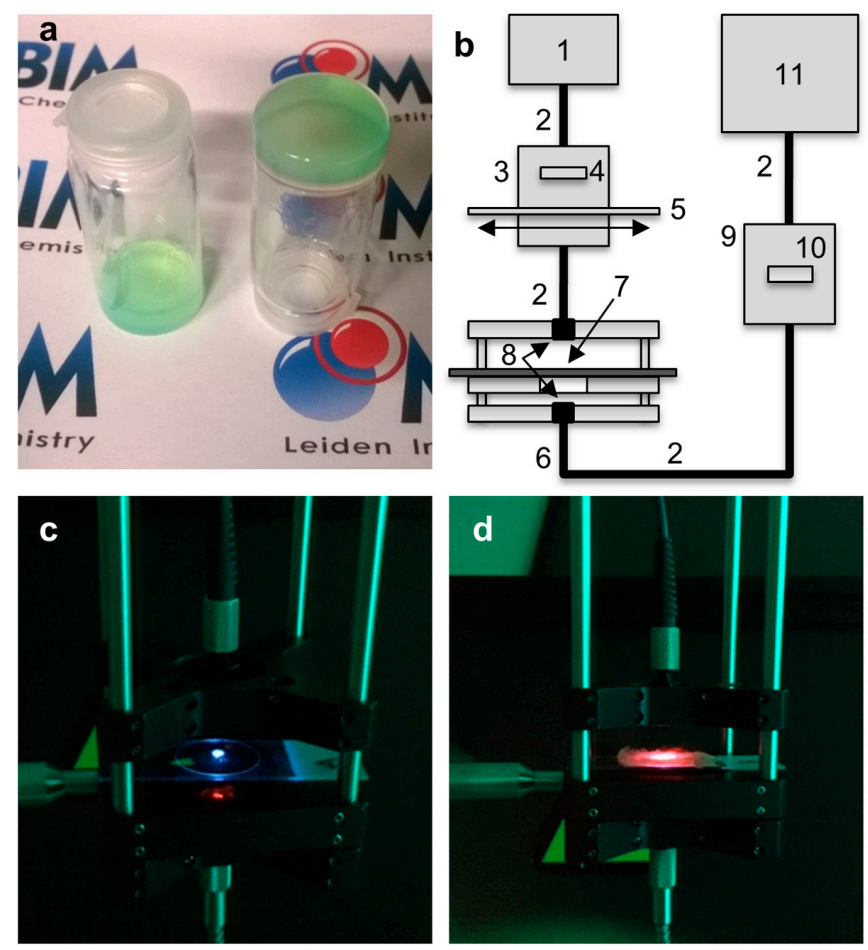

Figure 4. Upconversion spectroscopy with gellified L12 liposomes buried under meat. (a) Photograph of bulk gellified $\mathbf{L 1 2}$ liposomes in $0.5 \mathrm{wt} \%$ agarose gel in PBS containing $5 \mathrm{mM} \mathrm{L-Asc}$ and GSH; (b) Schematic representation of the experimental setup used for spectroscopy through meat: (1) $630 \mathrm{~nm}$ laser; (2) optical fibers; (3) filter holder for $630 \mathrm{~nm}$ band pass filter (4) and variable neutral density filter (5); (6) cage system with two oppositely facing cage plates, both fitted with a collimating lens (8), and a central sample-holding plate (7); (9) filter holder for a $630 \mathrm{~nm}$ notch filter (10); (11) CCD-spectrometer. Photographs of the cage spectroscopy setup with: the upconverting liposome gel only (c); and with 1 layer of pork fillet on top (d). Both photographs were taken with a $575 \mathrm{~nm}$ OD 4 short pass filter in front of the camera to block the excitation source. 
The emission spectra for both meat types showed the typical phosphorescence of $\mathbf{1}$ at $800 \mathrm{~nm}$ and upconversion emission of 2 at $474 \mathrm{~nm}$ (Figure 5a,c). As could be expected, the intensity of the entire spectrum decreased as a function of meat thickness due to filtering and scattering of the excitation source by the meat. However, upconversion was still observable for $12.8 \mathrm{~mm}$ thick chicken and for $11.6 \mathrm{~mm}$ thick pork. Figure $5 \mathrm{c}$,d shows the upconversion intensity $\left(I_{U C}\right)$, the phosphorescence of $\mathbf{1}\left(I_{p}\right)$, and their ratio $\left(I_{U C} / I_{p}\right)$ as a function of meat thickness. It can be clearly seen that from the third meat layer onwards, $I_{U C}$ decreases relatively faster than $I_{p}$, i.e., $I_{U C} / I_{p}$ decreases. This can be rationalized by the fact that TTA-UC is quadratically dependent on the excitation intensity below the intensity threshold for efficient upconversion $\left(I_{t h}\right)$, while the phosphorescence is linearly dependent. $I_{t h}$ was previously determined to be $0.05 \mathrm{~W} / \mathrm{cm}^{2}$ for very similar red-to-blue TTA-UC in DOPC liposomes [42]. Considering that $I_{U C} / I_{p}$ changes for the first time after three layers of meat, this must mean that the excitation intensity after three layers of meat has decreased from $0.57 \mathrm{~W} / \mathrm{cm}^{2}$ to approximately $0.05 \mathrm{~W} / \mathrm{cm}^{2}$ ). Overall, the results show that upconversion was generated beyond $10 \mathrm{~mm}$ penetration depth, but that, beyond 5 to $6 \mathrm{~mm}$ meat depth, the TTA-UC efficiency decreased rather quickly. Naturally, the depth at which the excitation intensity equals $I_{t h}$ depends on the initial excitation intensity, so it was decided that a higher irradiance was needed to activate Ru-prodrugs through meat (see below).
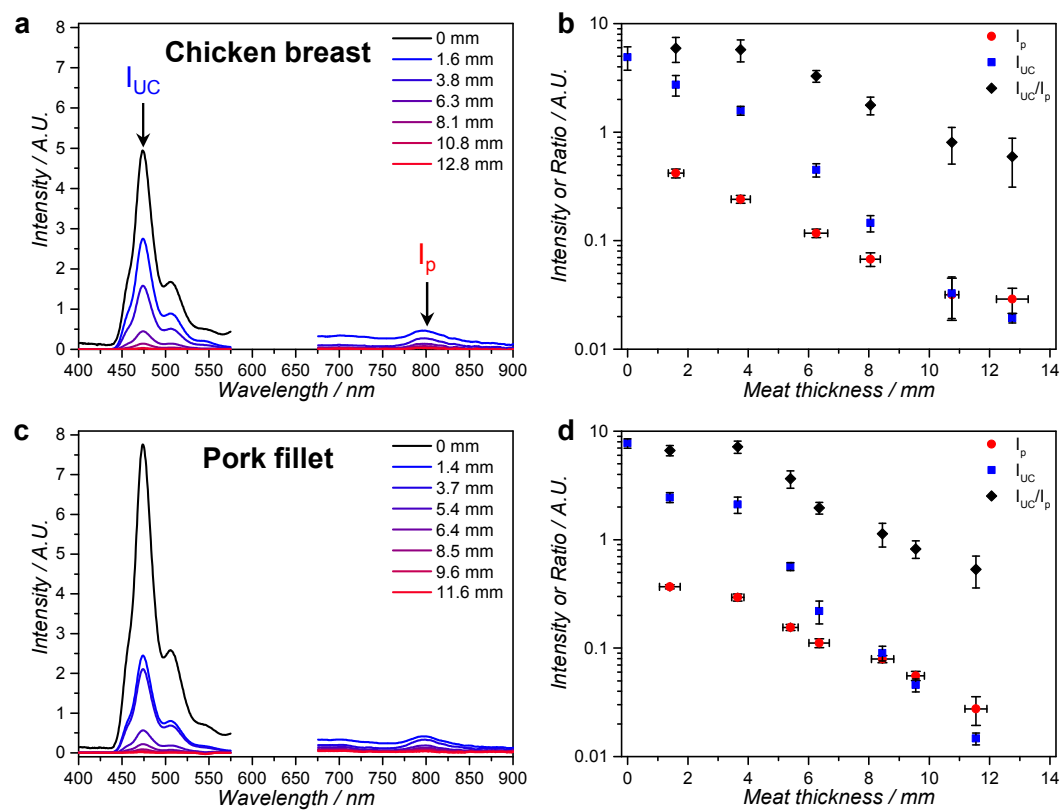

Figure 5. Emission spectroscopy of an upconverting liposome gel through layers of chicken breast or pork fillet. Emission spectra of gellified L12 liposomes through layers of meat at room temperature as a function of: chicken breast thickness (a); or pork fillet thickness (c). Upconversion intensity ( $I_{U C}$, at $474 \mathrm{~nm}$ ), phosphorescence intensity of compound $1\left(I_{p}\right)$ and the ratio of $I_{U C}$ and $I_{p}$ as a function of: chicken breast thickness (b) or pork fillet thickness (d). Conditions: $20 \mu \mathrm{L}$ sample in a $25 \mu \mathrm{m} \times 25 \mathrm{~mm}$ diameter disk of L12 liposomes ([DLPC] $=10 \mathrm{mM}$ ) in $0.5 \%$ wt $\%$ agarose gel, $5 \mathrm{mM}$ L-Asc, and $5 \mathrm{mM} \mathrm{GSH}$ in PBS at room temperature, irradiated with $30 \mathrm{~mW}\left(3 \mathrm{~mm}\right.$ spot, $0.57 \mathrm{~W} / \mathrm{cm}^{2}$ ) $630 \mathrm{~nm}$ light through a variable number of meat slices. The spectra are cut off between $575 \mathrm{~nm}$ and $675 \mathrm{~nm}$ to omit the large excitation scatter peak.

\subsection{Inducing TTA-UC and Drug Activation through Meat with DLPC Liposomes}

The real question in phototherapy, however, is whether it is really advantageous for the activation of $\mathrm{Ru}$ prodrugs to use red light and upconversion, or whether blue light, which penetrates less far into the tissue but triggers in a more straightforward manner the photosensitive compound, remains preferable. To compare both irradiation wavelengths, the photodissociation of $4^{2+}$ into $5^{2+}$ with 
red or blue light and L134 liposomes was attempted through a layer of pork fillet $(7 \pm 0.5 \mathrm{~mm})$ to simulate operation conditions. A $2 \mathrm{~mm}$ thick cuvette was filled with $400 \mu \mathrm{L}$ L134 liposomes $([D L P C]=10 \mathrm{mM})$ in a buffer containing $10 \mathrm{mM} \mathrm{L-Asc}$ and GSH, and then it was placed under the layer of pork fillet. The sample was irradiated through the meat with either red or blue light for $2 \mathrm{~h}$ (Figure 6a) with equal light doses for both experiments (110 mW laser light, $3 \mathrm{~mm}$ spot size, $1.6 \mathrm{~W} / \mathrm{cm}^{2}$, $11.2 \mathrm{~kJ} / \mathrm{cm}^{2}$ ). The UV-vis absorption spectrum of the cuvette (without meat) was measured before and after irradiation to investigate how much of $4^{2+}$ had been activated into $5^{2+}$ (Figure 6b). Unexpectedly, the absorption band that appeared between 460 and $600 \mathrm{~nm}$ indicated that similarly small quantities of the aqua species $5^{2+}$ (compare Figures $3 a$ and $6 \mathrm{~b}$ ) were obtained for both excitation wavelengths.
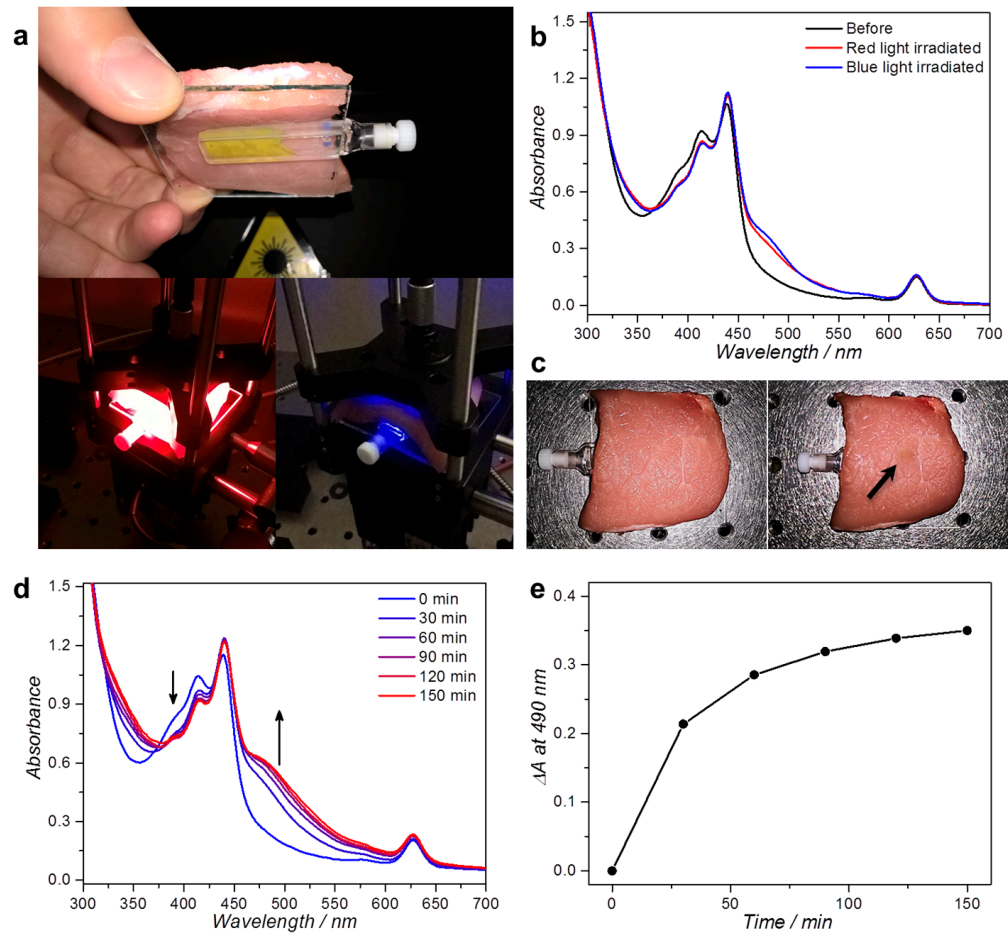

Figure 6. Irradiation of L134 liposomes through a thick slice of pork fillet. (a) Photographs of the experimental setup used for red and blue light irradiation. The $2 \mathrm{~mm}$ cuvette holding $400 \mu \mathrm{L} \mathrm{L134}$ $([D L P C]=10 \mathrm{mM})$ is covered with $7 \mathrm{~mm}$ pork fillet and irradiated for $2 \mathrm{~h}$ from above with a collimated $110 \mathrm{~mW} 630$ or $450 \mathrm{~nm}$ beam ( $3 \mathrm{~mm}$ spot size, $1.6 \mathrm{~W} / \mathrm{cm}^{2}$ intensity, $11.2 \mathrm{~kJ} / \mathrm{cm}^{2}$ light dose); (b) UV-vis absorbance spectra of the sample before (black) and after irradiation with $450 \mathrm{~nm}$ (blue) or $630 \mathrm{~nm}$ light (red); (c) Photographs of the pork fillet after red (left) or blue light irradiation (right). Upon blue light irradiation, a clear "burn mark" was observed, as indicated with the arrow. UV-vis absorbance spectra (d); and the absorbance difference at $490 \mathrm{~nm}$ (e) as a function of irradiation time for L134 liposomes irradiated through $7 \mathrm{~mm}$ pork fillet with $300 \mathrm{~mW} 630 \mathrm{~nm}$ light $\left(4.2 \mathrm{~W} / \mathrm{cm}^{2}\right)$. Experiment performed once. Arrows indicate the evolution of the spectrum in time near the indicated wavelengths.

This result can be interpreted by considering the two different photochemical pathways of activation. In the case of blue light, the light intensity quickly diminishes with penetration depth, but the photons that do reach the sample have a high chance of being absorbed due to the high absorbance of $4^{2+}$ at $450 \mathrm{~nm}\left(\varepsilon_{450} \approx 6000 \mathrm{M}^{-1} \cdot \mathrm{cm}^{-1},\left[4^{2+}\right]=0.40 \mathrm{mM} ; A_{450}^{4^{2+}} \approx 0.5\right.$ for $2 \mathrm{~mm}$ path length). In addition, upon blue light absorption, the complex is directly activated without intervention of TTA-UC, i.e., the chance is comparatively high that absorption of a blue photon causes photodissociation. In the case of red light, the light intensity diminishes much less quickly with meat thickness, i.e., more light reaches the cuvette for a given thickness than with blue light. However, the overall activation efficiency is the product of the upconversion quantum yield $\left(\Phi_{U C}\right)$, of the energy 
transfer efficiency from annihilator 3 to $4^{2+}\left(E_{E T}\right)$, and of the photodissociation quantum yield of the ruthenium complex $\left(\Phi_{R u}\right)$, which leads overall to a $\sim 20$ times lower activation efficiency [26]. In addition, the absorbance of compound 1 at $630 \mathrm{~nm}$ was comparatively low $\left(A_{630}^{1}=0.15\right)$, leading to less efficient use of the red light that permeates at higher intensities through the meat. Last but not least, at $1.6 \mathrm{~W} / \mathrm{cm}^{2} 630 \mathrm{~nm}$ excitation intensity, it is likely that $\Phi_{U C}$ is lower than its maximum value, because the excitation intensity likely drops to $I_{\text {th }}$ or below $\left(\sim 0.05 \mathrm{~W} / \mathrm{cm}^{2}\right)$. Thus, even though L134 liposomes are clearly more responsive to blue light, the data show that the overall activation rate with red light was approximately just as high as with blue light at the same power.

However, one observation was still missing: the state of the meat after $2 \mathrm{~h}$ irradiation. Visual inspection revealed that while red light had caused no apparent damage, blue light had clearly burned the meat considerably at the irradiation spot (Figure 6c). This result is consistent with in vitro data of our group that blue light is much more harmful for cells than green or red light [43]. In operation conditions, red light will not harm the superficial tissues, which is much more favorable than blue light. Tissue burns are also a great issue for lanthanoid-based upconversion nanoparticles (UCNPs). For instance, it has been shown by Wu et al. that irradiation of chicken meat with $980 \mathrm{~nm}$ laser light for $20 \mathrm{~min}$ at $\geq 5 \mathrm{~W} / \mathrm{cm}^{2}$ intensity causes significant burn marks. In the case of red-to-blue TTA-UC, our data show that upconversion-mediated drug activation is possible at relatively low power $(110 \mathrm{~mW})$ without any visible tissue ablation.

In the previous experiment, prodrug activation was limited to $10 \%-20 \%$ of the initially available amount of Ru compound notably because our blue laser could not provide higher light intensities. The red laser did not have such power limitations. To finally prove that it is possible to fully activate the ruthenium compound through meat, a similar red light irradiation experiment was repeated using higher intensity red light ( $300 \mathrm{~mW}, 4.2 \mathrm{~W} / \mathrm{cm}^{2}$ power density), and the absorption spectrum of the liposome solution was measured every $30 \mathrm{~min}$ (Figure $6 \mathrm{~d}, \mathrm{e}$ ). The absorption band for $5^{2+}$ between 460 and $600 \mathrm{~nm}$ reached a plateau after approximately $2 \mathrm{~h}$ of irradiation, which indicated that full activation could indeed be obtained provided the red light intensity and dose was high enough. Even at such power densities of red light no visible signs of irradiation damage or tissue burn were observed. In conclusion, our data show that activation of complex $4^{2+}$ by a combination of red light irradiation and TTA-UC was complete even through a $7 \mathrm{~mm}$ thick slice of pork fillet and under air. At such red light intensities, activation is not necessarily much faster than using blue light, but the compound is activated with much less tissue damage for any healthy tissue that may be surrounding the tumor.

\section{Materials and Methods}

\subsection{General}

Palladium tetraphenyltetrabenzoporphyrin (1) was purchased from Frontier Scientific, Inc. (Logan, UT, USA). Perylene (2) was purchased from Sigma-Aldrich Chemie BV (Zwijndrecht, The Netherlands). The synthesis of 2,5,8,11-tetra(tert-butyl)perylene (compound 3) is described elsewhere [25]. Sodium $N$-(carbonyl-methoxypolyethylene glycol-2000)-1,2-distearoyl-sn-glycero-3phosphoethanolamine (DSPE-mPEG-2000), 1,2-dilauroyl-sn-glycero-3-phosphocholine (DLPC), and 1,2-dimyristoyl-sn-glycero-3-phosphocholine (DMPC) were purchased from Lipoid GmbH (Ludwigshafen, Germany) and stored at $-18{ }^{\circ} \mathrm{C}$. Dulbecco's phosphate buffered saline (PBS) was purchased from Sigma Aldrich and had a formulation of $8 \mathrm{~g} / \mathrm{L} \mathrm{NaCl}, 0.2 \mathrm{~g} / \mathrm{L} \mathrm{KCl}, 0.2 \mathrm{~g} / \mathrm{L} \mathrm{KH} \mathrm{PO}_{4}$, and $1.15 \mathrm{~g} / \mathrm{L} \mathrm{K}_{2} \mathrm{HPO}_{4}$ with a $\mathrm{pH}$ of 7.1-7.5. Antioxidant supplemented PBS was prepared by dissolving L-ascorbic acid and/or glutathione in PBS and neutralizing with sodium hydroxide to $\mathrm{pH}$ 7.0-7.6. Other chemicals were purchased from major chemical suppliers and used as received. Data was processed with Origin Pro and Microsoft Excel software. Photodissociation experiments using blue light were recorded in a Varian Cary 50 spectrometer (Agilent Technologies, Amstelveen, The Netherlands) equipped with a Cary Single Cell Peltier for temperature control. 


\subsection{Synthesis of 1,3-Bis(methylthio)-2-dodecyloxypropane-Compound $\mathbf{6}$}

To a stirred suspension of $\mathrm{NaH}(222 \mathrm{mg}, 5.55 \mathrm{mmol})$ in dry and deoxygenated THF $(5 \mathrm{~mL})$ under Ar atmosphere was added 1,3-bis(methylthio)-2-propanol $(0.25 \mathrm{~mL}, 1.85 \mathrm{mmol})$. The mixture was stirred at RT for $10 \mathrm{~min}$, after which 1-bromododecane $(0.5 \mathrm{~mL}, 2.13 \mathrm{mmol})$ was added dropwise, resulting in a light-brown suspension. The reaction mixture was heated to reflux for $20 \mathrm{~h}$. Hereafter, the mixture was concentrated to $1-2 \mathrm{~mL}, \mathrm{Et}_{2} \mathrm{O}(40 \mathrm{~mL})$ was added, and the resulting mixture was washed with brine $(40 \mathrm{~mL}), 1 \mathrm{M}$ aq. $\mathrm{NH}_{4} \mathrm{Cl}(2 \times 40 \mathrm{~mL})$ and brine $(40 \mathrm{~mL})$. The organic layer was dried with $\mathrm{MgSO}_{4}$ and the solvent was removed by rotary evaporation. After column chromatography $\left(\mathrm{SiO}_{2}\right.$, petroleum ether 40-60:DCM (2:1) to neat DCM) the title compound was obtained as a light-yellow oil $(250 \mathrm{mg}, 0.78 \mathrm{mmol}, 42 \%)$. TLC: $R_{\mathrm{f}}=0.9$ (DCM). ${ }^{1} \mathrm{H}-\mathrm{NMR}\left(300 \mathrm{MHz}, \delta\right.$ in $\left.\mathrm{CDCl}_{3}\right): 3.58(\mathrm{p}, J=5.8 \mathrm{~Hz}$, $1 \mathrm{H}, \mathrm{H} 3), 3.51\left(\mathrm{t}, J=6.6 \mathrm{~Hz}, 2 \mathrm{H}, \mathrm{H1} 1^{\prime}\right), 2.74(\mathrm{ddd}, J=18.9,13.6,5.8 \mathrm{~Hz}, 4 \mathrm{H}, \mathrm{H} 2+\mathrm{H} 4), 2.16(\mathrm{~s}, 6 \mathrm{H}, \mathrm{H} 1+\mathrm{H} 5)$, 1.65-1.51 (m, 2H, H2'), 1.42-1.18 (m, 18H, H3'-H11'), $0.88\left(\mathrm{t}, J=6.5 \mathrm{~Hz}, 3 \mathrm{H}, \mathrm{H} 12^{\prime}\right) ;{ }^{13} \mathrm{C}-\mathrm{NMR}(75 \mathrm{MHz}$, $\delta$ in $\mathrm{CDCl}_{3}$ ): $79.3,70.3,37.7,32.1,30.2,29.8,29.8,29.8,29.7,29.6,29.5,26.3,22.8,16.9,14.3$; ESI-MS $\mathrm{m} / \mathrm{z}$ exp. (calcd.): $135.1\left(135.0,\left[\mathrm{M}-\mathrm{C}_{12} \mathrm{H}_{25} \mathrm{O}\right]^{+}\right), 208.0\left(208.2,\left[\mathrm{C}_{12} \mathrm{H}_{25} \mathrm{O}+\mathrm{Na}\right]^{+}\right), 321.2\left(321.2,[\mathrm{M}+\mathrm{H}]^{+}\right)$.

\subsection{Synthesis of $4\left(\mathrm{PF}_{6}\right)_{2}$}

A mixture of compound 6 (66 mg, $0.206 \mathrm{mmol})$ and cis- $\Lambda / \Delta-\left[\mathrm{Ru}(\mathrm{bpy})_{2} \mathrm{Cl}_{2}\right](50 \mathrm{mg}, 0.103 \mathrm{mmol})$ under Ar atmosphere was dissolved in a 1:1 mixture of $\mathrm{EtOH}$ and $\mathrm{H}_{2} \mathrm{O}(10 \mathrm{~mL})$ and heated to reflux in the dark for $20 \mathrm{~h}$. Hereafter, the reaction mixture was cooled to room temperature, and the solvent was removed in vacuo. The reaction mixture was poured onto $30 \mathrm{~mL}$ of sat. aq. $\mathrm{KPF}_{6}$, extracted with DCM $(4 \times 20 \mathrm{~mL})$, and concentrated by rotary evaporation. Removal of the excess ligand was done by centrifugal washing with diethyl ether $(2 \times 12 \mathrm{~mL}, 2800 \times g)$. cis- $\Lambda / \Delta-\left[\mathrm{Ru}(\mathrm{bpy})_{2}(6)\right](\mathrm{PF} 6)_{2}$ (compound $4\left(\mathrm{PF}_{6}\right)_{2}$ Scheme 2 ) was obtained as an orange powder in $45 \%$ yield $(47 \mathrm{mg}, 0.046 \mathrm{mmol}$ ). ${ }^{1} \mathrm{H}-\mathrm{NMR}\left(400 \mathrm{MHz}, \delta\right.$ in $\left.\mathrm{CD}_{3} \mathrm{CN}\right): 9.62\left(\mathrm{~d}, J=5.3 \mathrm{~Hz}, 1 \mathrm{H}, \mathrm{H}_{\mathrm{H}}\right), 9.17\left(\mathrm{~d}, J=5.3 \mathrm{~Hz}, 1 \mathrm{H}, \mathrm{H}_{\mathrm{h}}\right), 8.52$ $\left(\mathrm{t}, J=8.7 \mathrm{~Hz}, 2 \mathrm{H}, \mathrm{H}_{\mathrm{e}}+\mathrm{H}_{\mathrm{E}}\right), 8.38\left(\mathrm{dd}, J=8.2,2.8 \mathrm{~Hz}, 2 \mathrm{H}, \mathrm{H}_{\mathrm{d}}+\mathrm{H}_{\mathrm{D}}\right), 8.33-8.24\left(\mathrm{~m}, 2 \mathrm{H}, \mathrm{H}_{\mathrm{f}}+\mathrm{H}_{\mathrm{F}}\right), 8.03-7.96$ $\left(\mathrm{m}, 2 \mathrm{H}, \mathrm{H}_{\mathrm{c}}+\mathrm{H}_{\mathrm{C}}\right), 7.93-7.85\left(\mathrm{~m}, 2 \mathrm{H}, \mathrm{H}_{\mathrm{g}}+\mathrm{H}_{\mathrm{G}}\right), 7.49\left(\mathrm{~d}, J=5.1 \mathrm{~Hz}, 1 \mathrm{H}, \mathrm{H}_{\mathrm{A}}\right), 7.43\left(\mathrm{~d}, J=5.1 \mathrm{~Hz}, 1 \mathrm{H}, \mathrm{H}_{\mathrm{a}}\right)$, 7.36-7.26 (m, 2H, $\left.\mathrm{H}_{\mathrm{b}}+\mathrm{H}_{\mathrm{B}}\right), 4.37(\mathrm{~s}, 1 \mathrm{H}, \mathrm{H} 3), 3.67\left(\mathrm{dt}, J=9.2,6.5 \mathrm{~Hz}, 1 \mathrm{H}, \mathrm{H} 1^{\prime}\right), 3.49(\mathrm{dt}, J=9.2,6.5 \mathrm{~Hz}$, 1H, H1'), 3.20 (dd, J = 13.2, $6.2 \mathrm{~Hz}, 1 \mathrm{H}, \mathrm{H} 4), 3.12$ (dd, J = 13.9, $2.7 \mathrm{~Hz}, 1 \mathrm{H}, \mathrm{H} 2), 2.95$ (s, 1H, H2), 2.61 (dd, $J=13.1,1.6 \mathrm{~Hz}, 1 \mathrm{H}, \mathrm{H} 4), 1.66-1.54\left(\mathrm{~m}, 2 \mathrm{H}, \mathrm{H}^{\prime}\right), 1.43$ (s, 3H, H1), 1.40-1.21 (m, 18H, H3'-11'), 1.08 (s, $3 \mathrm{H}, \mathrm{H} 5), 0.88\left(\mathrm{~d}, J=6.8 \mathrm{~Hz}, 3 \mathrm{H}, \mathrm{H} 12^{\prime}\right) ;{ }^{13} \mathrm{C}-\mathrm{NMR}\left(100 \mathrm{MHz}, \delta\right.$ in $\left.\mathrm{CD}_{3} \mathrm{CN}\right): 158.6\left(\mathrm{C}_{\mathrm{q}}\right), 158.5\left(\mathrm{C}_{\mathrm{q}}\right), 157.3$ $\left(C_{\mathrm{q}}\right), 157.2\left(\mathrm{C}_{\mathrm{q}}\right), 154.6\left(\mathrm{C}_{\mathrm{h}}\right), 153.9\left(\mathrm{C}_{\mathrm{H}}\right), 152.2\left(\mathrm{C}_{\mathrm{a}}\right), 151.9\left(\mathrm{C}_{\mathrm{A}}\right), 139.8\left(\mathrm{C}_{\mathrm{c}}+\mathrm{C}_{\mathrm{C}}+\mathrm{C}_{\mathrm{f}}+\mathrm{C}_{\mathrm{F}}\right), 129.7\left(\mathrm{C}_{\mathrm{g}}\right)$, $128.7\left(\mathrm{C}_{\mathrm{b}}+\mathrm{C}_{\mathrm{B}}\right), 128.6\left(\mathrm{C}_{\mathrm{G}}\right), 125.9\left(\mathrm{C}_{\mathrm{e}}\right), 125.8\left(\mathrm{C}_{\mathrm{E}}\right), 125.2\left(\mathrm{C}_{\mathrm{d}}\right), 125.1\left(\mathrm{C}_{\mathrm{D}}\right), 74.2(\mathrm{C} 3), 70.4\left(\mathrm{C}^{\prime}\right), 38.0(\mathrm{C} 4)$, 37.2 (C2), 32.6, 30.5, 30.3, 30.3, 30.0, 26.8, 23.4, 20.9 (all C2'-11'), 18.5 (C1), 16.0 (C5), 14.4 (C12'); HR-MS $m / z$ exp. (calcd.): 367.1310 (367.1312, $\left.\left[\mathrm{M}-2 \mathrm{PF}_{6}\right]^{2+}\right)$; UV-Vis: $\lambda_{\max }\left(\varepsilon\right.$ in L/mol-cm) in $\mathrm{CH}_{3} \mathrm{CN}: 415 \mathrm{~nm}$ (6170); Elemental analysis for $\mathrm{C}_{37} \mathrm{H}_{52} \mathrm{~F}_{12} \mathrm{~N}_{4} \mathrm{OP}_{2} \mathrm{RuS}_{2}$ : (calcd.): $\mathrm{C}, 43.40 ; \mathrm{H}, 5.12 ; \mathrm{N}, 5.47$; (exp.): $\mathrm{C}, 43.38$; H, 5.15; N, 5.49.

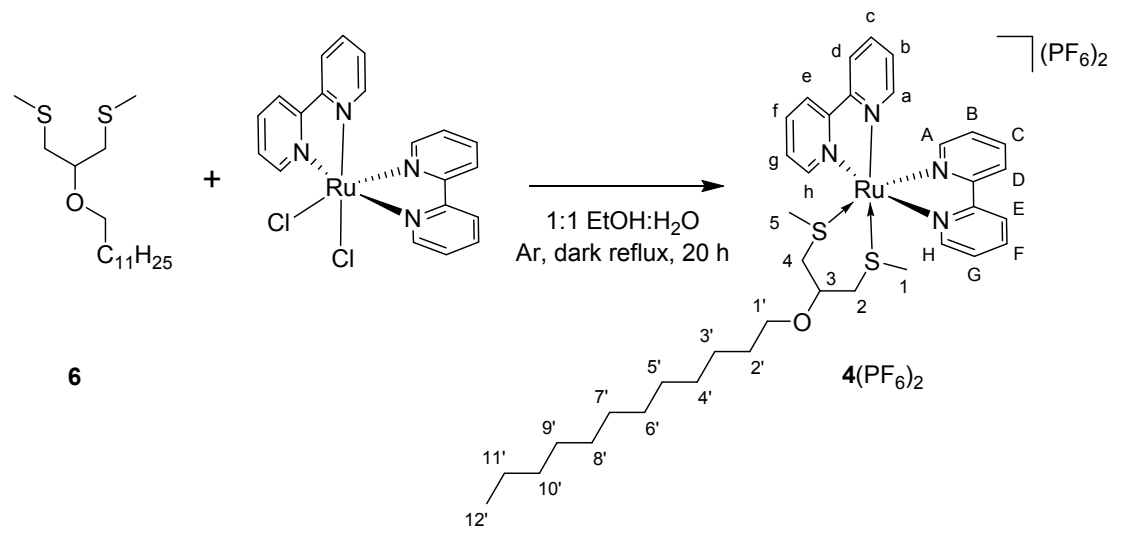

Scheme 2. Synthesis of $4\left(\mathrm{PF}_{6}\right)_{2}$ from compound 6 and cis- $\Lambda / \Delta-\left[\mathrm{Ru}(\mathrm{bpy})_{2} \mathrm{Cl}_{2}\right]$. 


\subsection{Liposome Preparation}

All liposome formulations were prepared by the classical hydration-extrusion method. As an example, the preparation of M134 is described here. Aliquots of chloroform stock solutions containing the liposome constituents were added together in a flask to obtain a solution with $5.0 \mu \mathrm{mol}$ DMPC, $0.20 \mu \mathrm{mol}$ DSPE-mPEG-2000, $2.5 \mathrm{nmol} \mathrm{1,} 25 \mathrm{nmol} \mathrm{3,} \mathrm{and} 0.20 \mu \mathrm{mol} \mathrm{4}\left(\mathrm{PF}_{6}\right)_{2}$. The organic solvent was removed by rotary evaporation and subsequently under high vacuum for at least 30 min to create a lipid film. One milliliter PBS buffer (with or without L-ascorbic acid and/or glutathione) was added and the lipid film was hydrated by 4 cycles of freezing the flask in liquid nitrogen and thawing in warm water $\left(50^{\circ} \mathrm{C}\right)$. The resulting dispersion was extruded through a Whatman Nuclepore $0.2 \mu \mathrm{m}$ polycarbonate filter at $40-50{ }^{\circ} \mathrm{C}$ at least 11 times using a mini-extruder from Avanti Polar Lipids, Inc. (Alabaster, AL, USA). The number of extrusions was always odd to prevent any unextruded material ending up in the final liposome sample. The extrusion filter remained practically colorless after extrusion, suggesting near-complete inclusion of the chromophoric compounds in the lipid bilayer. Liposomes were stored in the dark at $4{ }^{\circ} \mathrm{C}$ and used within 7 days. The average hydrodynamic liposome size and polydispersity index (PDI) were measured with a Zetasizer Nano-S machine from Malvern Instruments (Malvern, UK), operating at a wavelength of $632 \mathrm{~nm}$. The hydrodynamic diameter and polydispersity index (PDI) were typically $130-170 \mathrm{~nm}$ and 0.1 , respectively.

\subsection{Upconversion Emission Spectroscopy and Photodissociation Experiments with Red Light}

Upconversion emission spectroscopy and photodissociation experiments were conducted in a custom-built setup (Figure S8). All optical parts were connected with FC-UVxxx-2 (xxx = 200, 400, or 600) optical fibers from Avantes (Apeldoorn, The Netherlands), with a diameter of 200-600 $\mu \mathrm{m}$, respectively, and that were suitable for the UV-Vis range $(200-800 \mathrm{~nm})$. In the case of deoxygenation by argon bubbling, $1.5 \mathrm{~mL}$ of the diluted liposome sample was bubbled for at least $30 \mathrm{~min}$ in an external ice-cooled pear-shaped flask. After this period, bubbling was stopped while maintaining the argon flow, and the sample was warmed in a water bath of approximately $40{ }^{\circ} \mathrm{C}$ for $10 \mathrm{~min}$. Then, the sample was transferred by means of cannulation with argon pressure to a 111-OS macro fluorescence cuvette from Hellma (Müllheim, Germany) in a CUV-UV/VIS-TC temperature-controlled cuvette holder from Avantes. The sample was allowed to equilibrate at $310 \mathrm{~K}$ for an additional 10 min while stirring. The sample was held under argon atmosphere at a constant temperature of $310 \mathrm{~K}$ and irradiated for $4 \mathrm{~h}$ from the side with a $630 \mathrm{~nm}$ laser light beam from a clinical grade Diomed $630 \mathrm{~nm}$ PDT laser. The $630 \mathrm{~nm}$ light was filtered through a FB630-10, $630 \mathrm{~nm}$ band pass filter (Thorlabs, Dachau/Munich, Germany) put between the laser and the sample. The excitation power was controlled using a NDL-25C-4 variable neutral density filter (Thorlabs), and measured using a S310C thermal sensor connected to a PM100USB power meter (Thorlabs). The laser was collimated to a beam of $4 \mathrm{~mm}$ diameter with a power of 10 or $150 \mathrm{~mW}\left(0.080\right.$ or $1.2 \mathrm{~W} / \mathrm{cm}^{2}$ intensity); in such conditions, a cylinder of approximately $0.13 \mathrm{~cm}^{3}$ was simultaneously excited by the laser ( $8 \%$ of the total sample volume). UV-Vis absorption spectra were measured using an Avalight-DHc halogen-deuterium lamp (Avantes) as light source and a 2048L StarLine spectrometer (Avantes) as detector, both connected to the cuvette holder at a $180^{\circ}$ angle and both at a $90^{\circ}$ angle with respect to the red laser irradiation direction. The filter holder between cuvette holder and detector was in a position without a filter (Figure S8, item 8). Luminescence emission spectra were measured using the same detector but with the UV-Vis light source switched off. To visualize the spectrum from $450 \mathrm{~nm}$ to $900 \mathrm{~nm}$, while blocking the red excitation light, a Thorlabs NF-633 notch filter was used in the variable filter holder. For photodissociation experiments, a UV-Vis absorption and an emission spectra were measured every 15 min; each time the emission spectra were measured first by switching the filter holder to the appropriate position, then the laser was switched off, the halogen-deuterium lamp was turned on, the filter holder was switched to an open position, a UV-Vis absorption spectrum was recorded, the halogen-deuterium lamp was switched off, and the laser was switched on again. Each UV-Vis measurement took approximately $15 \mathrm{~s}$ 
in total. All spectra were recorded with Avasoft software from Avantes and further processed with Microsoft Office Excel 2010 and Origin Pro 9.1 software (OriginLab Corp., Northampton, MA, USA).

\subsection{Upconversion Emission Spectroscopy with L12 Liposomes and Meat}

L12 liposomes were prepared according to Section 3.4 ([DLPC] = $20.0 \mathrm{mM}$ ). To prepare a liposome hydrogel and to allow upconversion in air, this solution was heated to $55^{\circ} \mathrm{C}$ and $1: 1 \mathrm{v} / \mathrm{v}$ mixed with a solution at $55^{\circ} \mathrm{C}$ containing $1 \mathrm{wt} \%$ agarose, $10 \mathrm{mM}$ sodium L-ascorbate and $10 \mathrm{mM}$ sodium glutathionate ( $\mathrm{pH}$ 7.3). Twenty microliters of this mixture was pipetted with a warm pipet on a warm $1 \mathrm{~mm}$ thick microscopy slide (Menzel-Gläser Superfrost, $76 \times 26 \mathrm{~mm}$ ) and immediately covered with a round $25 \mathrm{~mm}$ diameter microscopy coverslip (VWR, thickness no. 1). Upon cooling to room temperature, this procedure produced a thin gel slice with $\sim 25 \mu \mathrm{m}$ thickness. On top of the coverslips, thin slices of chicken breast fillet or pork fillet were layered (1-2 mm thick each, measured for each slice with a caliper) up to $\sim 13 \mathrm{~mm}$ thick. The entire sample construct was allowed to reach room temperature $\left(20^{\circ} \mathrm{C}\right.$ ) before measurement in a custom-build spectroscopy setup (Figure 4). A cage with an open sample space was constructed with single collimating lenses (Avantes COL-UV/VIS) on both sides for excitation (from the top) and detection (from the bottom) connected with FC-UV400-2 or FC-UV600-2 optical fibers (Avantes). The excitation lens was connected to a clinical grade Diomed $630 \mathrm{~nm}$ PDT laser set to $30 \mathrm{~mW}$ ( $3 \mathrm{~mm}$ beam, $0.42 \mathrm{~W} / \mathrm{cm}^{2}$ ) using a PM100 USB power meter and S310C detector (Thorlabs). Between the laser and the excitation lens, a filter holder was placed with a FB630-10 band pass filter and a NDL-25C-4 variable neutral density filter (Thorlabs). The detection lens was connected to a 2048L StarLine spectrometer (Avantes); between the spectrometer and detection lens, a filter holder with a NF-633 notch filter was placed. For each meat layer thickness, the spectrum was taken at 5 different sample locations, and the spectrum was averaged. Then, a new layer of meat was carefully placed on top and the measurements were repeated until a thickness of $\sim 13 \mathrm{~mm}$ was achieved.

\subsection{Photodissociation Experiments with Meat}

For photodissociation experiments with L134 liposomes and meat, the sample was prepared as described in Section $3.4([D L P C]=10 \mathrm{mM})$. Four hundred microliters sample was placed in a $2 \mathrm{~mm}$ thick cuvette and sandwiched between a $5 \mathrm{~cm} \times 5 \mathrm{~cm}$ glass plate and a $5 \mathrm{~cm} \times 5 \mathrm{~cm}$ slice of pork fillet (Albert Heijn, Zaandam, The Netherlands; "AH Filetlapjes à la minute naturel"), $7 \pm 0.5$ mm thick. This meat-sample construct was placed in the same cage setup as described in Section 3.6, but the laser was now directly coupled to the excitation lens and the FB630-10 band pass filter was now placed directly between the excitation lens and the sample (see Figure 6). The detection lens and spectrometer were left out. To compare blue and light irradiation, the meat-sample construct was irradiated from the top with $110 \mathrm{~mW}$ of either $450 \mathrm{~nm}$ or $630 \mathrm{~nm}$ laser light in a $3 \mathrm{~mm}$ collimated beam $\left(1.6 \mathrm{~W} / \mathrm{cm}^{2}\right)$. In addition, the experiment was repeated with $300 \mathrm{~mW} 630 \mathrm{~nm}$ light $\left(4.2 \mathrm{~W} / \mathrm{cm}^{2}\right)$.

\section{Conclusions}

In this article, the biological applicability of upconverting liposomes for the activation of ruthenium-based anticancer prodrugs with red light was assessed. Using an antioxidant-supplemented buffer and air it was possible to obtain enough blue light upon red light irradiation of the liposomes to activate a $\mathrm{Ru}$ compound $\left(4^{2+}\right)$ located in the membrane containing the upconverting dyes. To approach the practical conditions of a phototherapeutic operation, it was first determined that upconverted blue light can still be generated by TTA-UC through more than $10 \mathrm{~mm}$ of chicken or pig meat. When filtering the excitation source with a $7 \mathrm{~mm}$ thick pork fillet slice, $\mathrm{Ru}$ photodissociation could be triggered at comparable rates either using blue light or red light $\left(1.6 \mathrm{~W} / \mathrm{cm}^{2}\right)$ and red-to-blue upconverting liposomes. However, significant tissue damage was obtained with blue light, whereas the same dose of red light did not lead to any observable tissue damage. It was then possible to increase the power density to $\sim 4 \mathrm{~W} / \mathrm{cm}^{2}$ to obtain full activation of the Ru compound with red light. Overall, 
these results pave the way for TTA-UC mediated photoactivation of photochemotherapeutic drugs in a biological context.

Supplementary Materials: Supplementary materials can be accessed at: http:/ /www.mdpi.com/1420-3049/21/ $11 / 1460 /$ s1.

Acknowledgments: The Dutch Organization for Scientific Research (NWO) is acknowledged for a VIDI grant to S.B. The European Research Council is acknowledged for a Starting Grant to S.B.E. Bouwman is kindly acknowledged for scientific discussion and support. Part of this research was performed as "short rotation" internship of the Holland Research School of Molecular Chemistry (HRSMC). The COST actions CM1403 "The European upconversion network-from the design of photon-upconverting nanomaterials to biomedical applications" and CM1105 "Functional metal complexes that bind to biomolecules" are acknowledged for stimulating scientific discussion.

Author Contributions: S.H.C.A. conceived, designed, and performed experiments and wrote the paper; M.S.M. contributed reagents and materials and performed the experiments; T.B. and I.L. performed the experiments; and S.B. supervised the project, wrote the paper, and arranged funding.

Conflicts of Interest: The authors declare no conflict of interest.

\section{References}

1. Goldbach, R.E.; Rodriguez-Garcia, I.; van Lenthe, J.H.; Siegler, M.A.; Bonnet, S. N-Acetylmethionine and Biotin as Photocleavable Protective Groups for Ruthenium Polypyridyl Complexes. Chem. Eur. J. 2011, 17, 9924-9929. [CrossRef] [PubMed]

2. Howerton, B.S.; Heidary, D.K.; Glazer, E.C. Strained Ruthenium Complexes Are Potent Light-Activated Anticancer Agents. J. Am. Chem. Soc. 2012, 134, 8324-8327. [CrossRef] [PubMed]

3. Loftus, L.M.; White, J.K.; Albani, B.A.; Kohler, L.; Kodanko, J.J.; Thummel, R.P.; Dunbar, K.R.; Turro, C. New $\mathrm{Ru}^{\mathrm{II}}$ Complex for Dual Activity: Photoinduced Ligand Release and ${ }^{1} \mathrm{O}_{2}$ Production. Chem. Eur. J. 2016, 22, 3704-3708. [CrossRef] [PubMed]

4. Arora, K.; White, J.K.; Sharma, R.; Mazumder, S.; Martin, P.D.; Schlegel, H.B.; Turro, C.; Kodanko, J.J. Effects of Methyl Substitution in Ruthenium Tris(2-pyridylmethyl)amine Photocaging Groups for Nitriles. Inorg. Chem. 2016, 55, 6968-6979. [CrossRef] [PubMed]

5. Farrer, N.J.; Salassa, L.; Sadler, P.J. Photoactivated chemotherapy (PACT): The potential of excited-state d-block metals in medicine. Dalton Trans. 2009, 48, 10690-10701. [CrossRef] [PubMed]

6. Ferrari, M. Cancer nanotechnology: Opportunities and challenges. Nat. Rev. Cancer 2005, 5, $161-171$. [CrossRef] [PubMed]

7. Matsumura, Y.; Maeda, H. A New Concept for Macromolecular Therapeutics in Cancer Chemotherapy: Mechanism of Tumoritropic Accumulation of Proteins and the Antitumor Agent Smancs. Cancer Res. 1986, 46, 6387-6392. [PubMed]

8. Weijer, R.; Broekgaarden, M.; Kos, M.; van Vught, R.; Rauws, E.A.J.; Breukink, E.; van Gulik, T.M.; Storm, G.; Heger, M. Enhancing photodynamic therapy of refractory solid cancers: Combining second-generation photosensitizers with multi-targeted liposomal delivery. J. Photochem. Photobiol. C Photochem. Rev. 2015, 23, 103-131. [CrossRef]

9. Allison, R.R.; Sibata, C.H. Oncologic photodynamic therapy photosensitizers: A clinical review. Photodiagn. Photodyn. Ther. 2010, 7, 61-75. [CrossRef] [PubMed]

10. Wagenknecht, P.S.; Ford, P.C. Metal centered ligand field excited states: Their roles in the design and performance of transition metal based photochemical molecular devices. Coord. Chem. Rev. 2011, 255, 591-616. [CrossRef]

11. Bahreman, A.; Cuello-Garibo, J.-A.; Bonnet, S. Yellow-light sensitization of a ligand photosubstitution reaction in a ruthenium polypyridyl complex covalently bound to a rhodamine dye. Dalton Trans. 2014, 43, 4494-4505. [CrossRef] [PubMed]

12. Higgins, S.L.H.; Brewer, K.J. Designing Red-Light-Activated Multifunctional Agents for the Photodynamic Therapy. Angew. Chem. Int. Ed. 2012, 51, 11420-11422. [CrossRef] [PubMed]

13. Liu, Q.; Feng, W.; Yang, T.; Yi, T.; Li, F. Upconversion luminescence imaging of cells and small animals. Nat. Protoc. 2013, 8, 2033-2044. [CrossRef] [PubMed] 
14. Kim, J.-H.; Kim, J.-H. Encapsulated Triplet-Triplet Annihilation-Based Upconversion in the Aqueous Phase for Sub-Band-Gap Semiconductor Photocatalysis. J. Am. Chem. Soc. 2012, 134, 17478-17481. [CrossRef] [PubMed]

15. Mahato, P.; Monguzzi, A.; Yanai, N.; Yamada, T.; Kimizuka, N. Fast and long-range triplet exciton diffusion in metal-organic frameworks for photon upconversion at ultralow excitation power. Nat. Mater. 2015, 14, 924-930. [CrossRef] [PubMed]

16. Zhou, J.; Liu, Q.; Feng, W.; Sun, Y.; Li, F. Upconversion Luminescent Materials: Advances and Applications. Chem. Rev. 2014, 115, 395-465. [CrossRef] [PubMed]

17. Singh-Rachford, T.N.; Castellano, F.N. Photon upconversion based on sensitized triplet-triplet annihilation. Coord. Chem. Rev. 2010, 254, 2560-2573. [CrossRef]

18. Hisamitsu, S.; Yanai, N.; Kimizuka, N. Photon-Upconverting Ionic Liquids: Effective Triplet Energy Migration in Contiguous Ionic Chromophore Arrays. Angew. Chem. Int. Ed. 2015, 54, 11550-11554. [CrossRef] [PubMed]

19. Lee, S.H.; Thévenaz, D.C.; Weder, C.; Simon, Y.C. Glassy poly(methacrylate) terpolymers with covalently attached emitters and sensitizers for low-power light upconversion. J. Polym. Sci. Part A Polym. Chem. 2015, 53, 1629-1639. [CrossRef]

20. Duan, P.; Yanai, N.; Nagatomi, H.; Kimizuka, N. Photon Upconversion in Supramolecular Gel Matrices: Spontaneous Accumulation of Light-Harvesting Donor-Acceptor Arrays in Nanofibers and Acquired Air Stability. J. Am. Chem. Soc. 2015, 137, 1887-1894. [CrossRef] [PubMed]

21. Duan, P.; Yanai, N.; Kimizuka, N. Photon Upconverting Liquids: Matrix-Free Molecular Upconversion Systems Functioning in Air. J. Am. Chem. Soc. 2013, 135, 19056-19059. [CrossRef] [PubMed]

22. Svagan, A.J.; Busko, D.; Avlasevich, Y.; Glasser, G.; Baluschev, S.; Landfester, K. Photon energy upconverting nanopaper: A bioinspired oxygen protection strategy. ACS Nano 2014, 8, 8198-8207. [CrossRef] [PubMed]

23. Kim, J.-H.; Kim, J.-H. Triple-Emulsion Microcapsules for Highly Efficient Multispectral Upconversion in the Aqueous Phase. ACS Photonics 2015, 2, 633-638. [CrossRef]

24. Huang, Z.; Li, X.; Mahboub, M.; Hanson, K.; Nichols, V.; Le, H.; Tang, M.L.; Bardeen, C.J. Hybrid moleculenanocrystal photon upconversion across the visible and near-infrared. Nano Lett. 2015, 15, 5552-5557. [CrossRef] [PubMed]

25. Askes, S.H.C.; Pomp, W.; Hopkins, S.L.; Kros, A.; Wu, S.; Schmidt, T.; Bonnet, S. Imaging Upconverting Polymersomes in Cancer Cells: Biocompatible Antioxidants Brighten Triplet-Triplet Annihilation Upconversion. Small 2016, 12, 5579-5590. [CrossRef] [PubMed]

26. Askes, S.H.C.; Kloz, M.; Bruylants, G.; Kennis, J.T.; Bonnet, S. Triplet-triplet annihilation upconversion followed by FRET for the red light activation of a photodissociative ruthenium complex in liposomes. Phys. Chem. Chem. Phys. 2015, 17, 27380-27390. [CrossRef] [PubMed]

27. Askes, S.H.C.; Bahreman, A.; Bonnet, S. Activation of a Photodissociative Ruthenium Complex by Triplet-Triplet Annihilation Upconversion in Liposomes. Angew. Chem. Int. Ed. 2014, 53, 1029-1033. [CrossRef] [PubMed]

28. Liu, Q.; Yang, T.; Feng, W.; Li, F. Blue-Emissive Upconversion Nanoparticles for Low-Power-Excited Bioimaging in Vivo. J. Am. Chem. Soc. 2012, 134, 5390-5397. [CrossRef] [PubMed]

29. Nagai, A.; Miller, J.B.; Kos, P.; Elkassih, S.; Xiong, H.; Siegwart, D.J. Tumor Imaging Based on Photon Upconversion of Pt(II) Porphyrin Rhodamine Co-modified NIR Excitable Cellulose Enhanced by Aggregation. ACS Biomater. Sci. Eng. 2015, 1, 1206-1210. [CrossRef]

30. Wohnhaas, C.; Mailänder, V.; Dröge, M.; Filatov, M.A.; Busko, D.; Avlasevich, Y.; Baluschev, S.; Miteva, T.; Landfester, K.; Turshatov, A. Triplet-Triplet Annihilation Upconversion Based Nanocapsules for Bioimaging Under Excitation by Red and Deep-Red Light. Macromol. Biosci. 2013, 13, 1422-1430. [CrossRef] [PubMed]

31. Wohnhaas, C.; Turshatov, A.; Mailänder, V.; Lorenz, S.; Baluschev, S.; Miteva, T.; Landfester, K. Annihilation Upconversion in Cells by Embedding the Dye System in Polymeric Nanocapsules. Macromol. Biosci. 2011, 11, 772-778. [CrossRef] [PubMed]

32. Liu, Q.; Yin, B.; Yang, T.; Yang, Y.; Shen, Z.; Yao, P.; Li, F. A General Strategy for Biocompatible, High-Effective Upconversion Nanocapsules Based on Triplet-Triplet Annihilation. J. Am. Chem. Soc. 2013, 135, 5029-5037. [CrossRef] [PubMed]

33. Kwon, O.S.; Song, H.S.; Conde, J.; Kim, H.-I.; Artzi, N.; Kim, J.-H. Dual-Color Emissive Upconversion Nanocapsules for Differential Cancer Bioimaging In Vivo. ACS Nano 2016, 10, 1512-1521. [CrossRef] [PubMed] 
34. Mongin, C.; Golden, J.H.; Castellano, F.N. Liquid PEG Polymers Containing Antioxidants: A Versatile Platform for Studying Oxygen-Sensitive Photochemical Processes. ACS Appl. Mater. Interfaces 2016, 8, 24038-24048. [CrossRef] [PubMed]

35. Kwon, O.S.; Kim, J.H.; Cho, J.K.; Kim, J.H. Triplet-triplet annihilation upconversion in CdS-decorated $\mathrm{SiO}_{2}$ nanocapsules for sub-bandgap photocatalysis. ACS Appl. Mater. Interfaces 2015, 7, 318-325. [CrossRef] [PubMed]

36. Kim, J.-H.; Deng, F.; Castellano, F.N.; Kim, J.-H. Red-to-Blue/Cyan/Green Upconverting Microcapsules for Aqueous- and Dry-Phase Color Tuning and Magnetic Sorting. ACS Photonics 2014, 1, 382-388. [CrossRef]

37. Marsico, F.; Turshatov, A.; Peköz, R.; Avlasevich, Y.; Wagner, M.; Weber, K.; Donadio, D.; Landfester, K.; Baluschev, S.; Wurm, F.R. Hyperbranched Unsaturated Polyphosphates as Protective Matrix for Long-Term Photon Upconversion in Air. J. Am. Chem. Soc. 2014, 136, 11057-11064. [CrossRef] [PubMed]

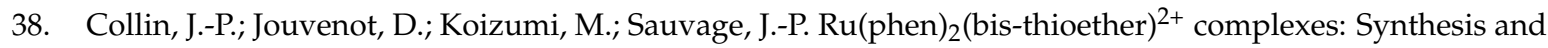
photosubstitution reactions. Inorg. Chim. Acta 2007, 360, 923-930. [CrossRef]

39. Garner, R.N.; Joyce, L.E.; Turro, C. Effect of Electronic Structure on the Photoinduced Ligand Exchange of $\mathrm{Ru}(\mathrm{II})$ Polypyridine Complexes. Inorg. Chem. 2011, 50, 4384-4391. [CrossRef] [PubMed]

40. Askes, S.H.C.; Brodie, P.; Bruylants, G.; Bonnet, S. Temperature dependence of triplet-triplet annihilation upconversion in phospholipid membranes. J. Phys. Chem. B. Manuscript under review.

41. Meister, A.; Anderson, M.E. Glutathione. Annu. Rev. Biochem. 1983, 52, 711-760. [CrossRef] [PubMed]

42. Askes, S.H.C.; Lopez Mora, N.; Harkes, R.; Koning, R.I.; Koster, B.; Schmidt, T.; Kros, A.; Bonnet, S. Imaging the lipid bilayer of giant unilamellar vesicles using red-to-blue light upconversion. Chem. Commun. 2015, 51, 9137-9140. [CrossRef] [PubMed]

43. Hopkins, S.L.H.; Siewert, B.; Askes, S.H.C.; van Veldhuizen, P.; Zwier, R.; Heger, M.; Bonnet, S. In vitro cell irradiation protocol for testing phytopharmaceuticals and the effect of blue, green, and red light on human cancer cell lines. Photochem. Photobiol. Sci. 2016, 15, 644-653. [CrossRef] [PubMed]

Sample Availability: Samples of the compounds 3 and $4^{2+}$ are available from the authors.

(C) 2016 by the authors; licensee MDPI, Basel, Switzerland. This article is an open access article distributed under the terms and conditions of the Creative Commons Attribution (CC-BY) license (http://creativecommons.org/licenses/by/4.0/). 